\title{
Seasonal effects of photophysiology and chlorophyll $a$ abundance on phytoplankton group-specific primary production in the Kuroshio region as revealed by SeaStar/SeaWiFS
}

5 Takafumi Hirata ${ }^{1}$, Koji Suzuki $^{1}$

${ }^{1}$ Faculty of Environmental Earth Science, Hokkaido University, Sapporo, 060-0810, Japan

Correspondence to: Takafumi Hirata (tahi@ees.hokudai.ac.jp)

Abstract.

To evaluate the group-specific primary production of diatoms, haptophytes, and cyanobacteria in the

10 Kuroshio region, a novel satellite observation methodology using the SeaStar/SeaWiFS satellite instrument was developed. The method used bio-optical relationships between the group-specific production and bio-optical properties such as the photosynthetic quantum yield and chlorophyll $a$ specific optical absorption coefficient of phytoplankton, the last two of which were also estimated together with the group-specific production rather than assumed a priori. A global property of the

15 absorption coefficient of phytoplankton, that the coefficient value at the wavelength of $510 \mathrm{~nm}$ was close to their spectral average, was highlighted in the method for a use of multi-spectral ocean color satellite data. Our results showed that the derived quantum yield index was higher for diatoms than haptophytes and cyanobacteria. Furthermore, intraspecific variation in the index, emerged as a latitudinal gradient: the values for cyanobacteria increased towards the higher latitudes. The group-

20 specific primary production in the Kuroshio region showed that the climatological average of 134,72 and $40 \mathrm{mg} \mathrm{C} \mathrm{m}^{-2} \mathrm{day}^{-1}$ for diatoms, haptophytes, and cyanobacteria, respectively. A comparison among variability of the group-specific primary production, the quantum yield index, and the absorption coefficient suggested that, in the Kuroshio region, the primary production due to diatoms was driven by their abundance through the year, whereas that due to cyanobacteria by photophysiology. The 25 production due to haptophytes was seasonally regulated by both abundance and photophysiology. 
Biogeosciences Discuss., doi:10.5194/bg-2017-164, 2017

Manuscript under review for journal Biogeosciences

Discussion started: 8 May 2017

(c) Author(s) 2017. CC-BY 3.0 License.

\section{Introduction}

The Kuroshio Current is the western boundary current carrying warm oligotrophic waters from the subtropic to the sub-arctic in the southwest region of the North Pacific (Fig. 1). Despite the oligotrophy of the current, higher fishery production has been recognized in and around the current, which is a

30 paradox of the Kuroshio ecosystems. Understanding the physical-biogeochemical-biological mechanisms of the Kuroshio ecosystems is crucial to not only explain this paradox as a science, but also provide a scientific basis for so-called ecosystem-based fishery management (Pikitch et al., 2004).

Recent advances in fishery sciences have revealed that the Kuroshio Current provides habitats for the larvae of pelagic fish as well as spawning grounds upstream (e.g., Sassa et al., 2004). In

35 addition, the oligotrophic Kuroshio Current meets a cold and nutrient-rich subarctic current, the Oyashio Current, forming a heterogeneous sub-polar front and eddies where primary production is fueled by vertical nutrient fluxes associated with physical instabilities at the front via upward transport of nutrients (Nagai et al., 2012; Clayton et al., 2014). In such a turbulent environment, diatoms with higher nutrient and/or low grazing mortality rates can become predominant in the phytoplankton

40 assemblages. Because diatoms have a dense silica wall and sink well in calm water, it is clear that turbulent upward motion is needed to keep them in the water column and is a prerequisite for the formation of dense populations of diatoms (Mann and Lazier, 2006). It is well known that many great fisheries are dependent on a grazing food chain that starts at diatoms and proceeds via copepods to young fish (Cushing, 1989). Therefore, understanding the community structure of primary producers

45 provides clues of the underlying ecological structure.

In a case study in the North Atlantic, Claustre et al. (2005) derived primary production parameters by the multiple regression analysis of in situ data and demonstrated that they were dependent on the phytoplankton community structure, and Uitz et al., (2008) further parameterized them. However, the Kuroshio region was not included in their analysis. Remote estimations of size-

50 fractionated primary production have also been conducted (Kameda and Ishizaka, 2005; Uitz et al., 2010) covering larger geographical extents to support intermittent efforts of in situ observations of size-fractionated or taxon-specific primary production (Owens et al., 1993; Jochem et al., 1995; Lee et al., 1996; Bury et al., 2001; Claustre et al., 2005; Moran et al., 2004; Barnes et al., 2014; Robinson et al., 2017). While remote sensing of size-specific primary production revealed a synoptic view of 55 community-resolved primary production, uncertainty remains due to regional variability in the 
Biogeosciences Discuss., doi:10.5194/bg-2017-164, 2017

Manuscript under review for journal Biogeosciences

Discussion started: 8 May 2017

(c) Author(s) 2017. CC-BY 3.0 License.

physiological properties in association with the ambient environment such as the sea temperature (Carr et al., 2006).

Our objective in this study is to estimate the regional, geographical patterns of the groupspecific primary production (i.e., diatoms, haptophytes, and cyanobacteria) and the related

60 photosynthetic properties in the Kuroshio Current and its adjacent waters in the North Pacific. We have developed a novel remote sensing methodology by integrating an image processing technique with a bio-optical model, and relaxing the assumptions of a certain physiology-environment association made in the previous approaches: the group-specific photophysiological properties, such as the quantum yield index (i.e. a scaled quantum yield) and the chlorophyll-specific absorption coefficient, are also obtained from space in this paper.

\section{Material and Method}

\subsection{Material}

\subsubsection{In situ data}

70 In this analysis, we defined the Kuroshio region as the area between 120 to $160^{\circ} \mathrm{E}$ and 24 to $44^{\circ} \mathrm{N}$, which includes the Kuroshio Current itself (shown schematically as a white arrow in Fig. 1) and adjacent waters. The southern side of the Kuroshio is characterized as a subtropical water whereas the northern side as a sub-polar water. We used in situ measurements of phytoplankton pigments measured with High Performance Liquid Chromatography (HPLC) and the spectral optical absorption coefficient

75 of phytoplankton, $a_{p h}(\lambda)$ where a wavelength is denoted by $\lambda$. The HPLC pigments were used to calibrate a satellite algorithm, OC-PFT (Hirata et al., 2011), to derive the phytoplankton composition in the Kuroshio region, while the absorption coefficient was used in a bio-optical model to estimate the group-specific primary production.

Water samples for the HPLC pigment analysis (Suzuki et al., 2015) were collected during

80 several cruises: the R/V Tansei-Maru KT-12-31 cruise from November 18 to 22, 2012 (Fig. 1). Diagnostic Pigment Analysis (Vidussi et al., 2001; Uitz et al., 2006) was then applied to define the pigment-based taxonomic composition of the phytoplankton. Only the surface data $(<10 \mathrm{~m})$ was used in our analysis $(\mathrm{N}=28)$. 
Biogeosciences Discuss., doi:10.5194/bg-2017-164, 2017

Manuscript under review for journal Biogeosciences

Discussion started: 8 May 2017

(c) Author(s) 2017. CC-BY 3.0 License.

The absorption data was only available for the R/V Soyo-Maru SY-13-04 cruise. To increase

85 robustness of our analysis, all absorption data from the surface to the maximum of 59 m were included in our analysis $(n=17)$. As shown in Section 3.1, that did not affect our result but rather supported the general applicability of our bio-optical model over different spaces (horizontally and vertically). The absorption coefficient was measured using the filter pad technique (Mitchell et al., 2000) with a pathlength correction scheme (Cleveland and Weidemann, 1993). We also used surface absorption data

90 from geographically distinct regions, such as the Benguela upwelling waters (Fishwick et al., 2006) and other globally located regions (Werdell and Bailey, 2005), to support robustness of a bio-optical model.

\subsubsection{Satellite data}

Our estimation of the group-specific primary productivity requires satellite data of (1) the

95 chlorophyll $a$ concentration, Chla $\left[\mathrm{mg} \mathrm{m}^{-3}\right]$; (2) the absorption coefficient of the total phytoplankton community at $510 \mathrm{~nm}, a_{p h}\left[\mathrm{~m}^{-1}\right]$; (3) the primary production of the total phytoplankton community, $P P\left[\mathrm{mg} \mathrm{C} \mathrm{m}^{-2} \mathrm{day}^{-1}\right]$; and (4) the Photosynthetically Available Radiation, $P A R\left[\mu \mathrm{mol} \mathrm{m} \mathrm{m}^{-2} \mathrm{day}^{-1}\right]$ as inputs. The Level 3 SeaWiFS (Sea-viewing Wide Field of View Sensor) monthly 9 km remote sensing reflectance, $R_{r s}\left[\mathrm{sr}^{-1}\right]$, at wavelengths of $412 \mathrm{~nm}, 443 \mathrm{~nm}, 490 \mathrm{~nm}, 510 \mathrm{~nm}$, and $555 \mathrm{~nm}$, Chla, and PAR

100 for the period of 1998-2007 were obtained from NASA. The remote sensing reflectance was inverted to derive $a_{p h}$ using the inversion model of Smyth et al. (2006). In addition, Chla derived from $R_{r s}$ (O’Reilly et al., 1998) was used to derive the relative abundance of the three phytoplankton taxonomic groups (i.e., diatoms, haptophytes, and cyanobacteria [\%]) following the procedure of Hirata et al. (2011), which was specifically calibrated for in situ data of the phytoplankton community structure in

105 the Kuroshio region described in the previous section; see Fig. 2. The relative abundance of each phytoplankton group was subsequently multiplied by Chla to obtain the group-specific Chla, that is, Chla ${ }_{i}\left[\mathrm{mg} \mathrm{m}^{-3}\right]$. Values of $P P$ for the total phytoplankton community derived from the Carbon-based Production Model (CbPM, Westeberry et al., 2008) with the same temporal and spatial resolutions as the SeaWiFS products were obtained from Oregon State University

110 (http://www.science.oregonstate.edu/ocean.productivity/).

\subsection{Methodology}


Biogeosciences Discuss., doi:10.5194/bg-2017-164, 2017

Manuscript under review for journal Biogeosciences

Discussion started: 8 May 2017

(c) Author(s) 2017. CC-BY 3.0 License.

\subsubsection{Bio-optical model of taxon-specific primary production}

115

Because most of the satellite signal originates from the surface of a water column, the depth dependency of the quantities described hereafter will be omitted for brevity, unless otherwise stated.

Primary productivity of the total phytoplankton community is expressed by the quantum yield of photosynthesis, $\Phi\left[\mathrm{mg} \mathrm{C} \mu \mathrm{mol}^{-1}\right], a_{p h}$, and PAR:

$$
\begin{aligned}
P P & =\Phi \cdot \int_{400}^{700} E_{0}(\lambda) \cdot a_{p h}(\lambda) d \lambda \\
& =\Phi \cdot P A R^{e f f} \cdot \int_{400}^{700} a_{p h}(\lambda) d \lambda \\
& =300 \cdot \Phi \cdot E^{*} \cdot P A R \cdot \chi_{a p h}(\lambda) \cdot a_{p h}(\lambda)
\end{aligned}
$$

125 where $\lambda$ is the wavelength $[\mathrm{nm}]$ and $E_{0}$ is the quantum number $\left[\mu \mathrm{mol} \mathrm{m}{ }^{-2}\right.$ day ${ }^{-1}$, which is related to PAR via $P A R=\int_{400}^{700} E_{0}(\lambda) d \lambda$. The effective PAR $\left(\mathrm{PAR}^{\mathrm{eff}}\right)\left[\mu \mathrm{mol} \mathrm{m} \mathrm{m}^{-2} \mathrm{day}^{-1}\right]$ is defined by $\int_{400}^{700} E_{0}(\lambda) a_{p h}(\lambda) d \lambda / \int_{400}^{700} a_{p h}(\lambda) d \lambda$, and $E^{*}$ [dimensionless] is the ratio between PAR $^{\text {eff }}$ and the actual PAR. Finally, $\chi_{a p h}(\lambda)$ is a factor converting $a_{p h}(\quad)$ to its spectral average, $\overline{a_{p h}(\lambda)}$, over the range of 400-700 $\mathrm{nm}$, that is, $\chi_{a p h}(\lambda)=\left(\int_{400}^{700} a_{p h}(\lambda) d \lambda / 300\right) / a_{p h}(\lambda)=\overline{a_{p h}(\lambda)} / a_{p h}(\lambda)$. Equation

130 (1) shows that $P P$ is proportional to $\chi_{a p h}(\lambda) \cdot a_{p h}(\lambda)\left(=\overline{a_{p h}}\right)$ with a light-dependent proportional factor, $300 \cdot \Phi \cdot E^{*} \cdot P A R$. Previous in situ observations (Marra et al., 2007) demonstrated a linear relationship between $P P$ and $\overline{a_{p h}(\lambda)}$, with different slopes depending on the study site. Thus, Eq. (1) explains the observation. On the other hand, a care must be taken that the proportionality factor, $300 \cdot \Phi \cdot E^{*} \cdot P A R$ is site-dependent, and can vary temporally and spatially, so that a comparison

135 between $P P$ and $\chi_{a p h}(\lambda) \cdot a_{p h}(\lambda)\left(=\overline{a_{p h}(\lambda)}\right)$ can also lead to non-linearity if the data pairs of $P P$ and $\chi_{a p h}(\lambda) \cdot a_{p h}(\lambda)$ (or $\overline{a_{p h}(\lambda)}$ ) are obtained at different locations (both horizontally and vertically) and/or time (Hirata et al., 2009).

Our data from the Kuroshio region show a hinge point at approximately $510 \mathrm{~nm}$ in the $\chi_{a p h}(\lambda)$ spectra (Fig. 3a). It corresponds to the central wavelength of one of the SeaWiFS wavebands 
Biogeosciences Discuss., doi:10.5194/bg-2017-164, 2017

Manuscript under review for journal Biogeosciences

Discussion started: 8 May 2017

(c) Author(s) 2017. CC-BY 3.0 License.

140 but neither of MODIS (Moderate Resolution Imaging Spectroradiometer) onboard the Aqua/Terra satellites nor VIIRS (Visible Infrared Imaging Radiometer Suite) onboard the Suomi National PolarOrbiting Partnership satellite. Values of $\chi_{a p h}(510)$ are approximately 0.973 , close to unity. The coefficient of variation $(\mathrm{CV})$ at $510 \mathrm{~nm}$ also displays one of the lowest values, 0.035 (Fig. 3). The same analysis for the biologically productive Benguela upwelling waters, which are geographically and

145 ecologically different from the Kuroshio region, shows $\chi_{a p h}(510)=0.882$ (Fig. 3b). The CV (0.035) at $510 \mathrm{~nm}$ is close to the minimum (0.034) found at $501 \mathrm{~nm}$ (the wavelength of $501 \mathrm{~nm}$ is however not used by historical ocean colour instruments). Furthermore, the global dataset (the NASA bio-Optical Marine Algorithm Dataset, NOMAD, Werdell and Bailey 2005) returned $\chi_{a p h}(510)=0.992$ with one of the lowest CV values of 0.087 , when discrete measurements of $a_{p h}(\lambda)$ is interpolated over the

150 spectrum (Fig. 3c). The small variability in $\chi_{a p h}(510)(=0.949 \pm 0.06)$ over the three different datasets shows the quasi-constant characteristic of $\chi_{a p h}(510)$ despite the large geographical differences between these datasets. Subsequently, $\overline{a_{p h}(\lambda)}$ can often be approximated by $\chi_{a p h}(510)$. $a_{p h}(510)$ worldwide with a quasi-constant value of $\chi_{a p h}(510)$. Note that our data from the Kuroshio included not only horizontal but also vertical distribution of $a_{p h}(\lambda)$, supporting this approximation. The

155 small variability in $\chi_{a p h}(510)$ over large geographical and temporal scales implicitly indicates that $\chi_{a p h}(510)$ is also quasi-constant irrespective of phytoplankton community structure.

When Eq. (1) is applied to each phytoplankton group, the group-specific primary production $P P_{i}$ is expressed by

$160 P P_{i}=A_{i}^{510} \Phi_{i}^{\#}$

where the quantum yield index is given by $\Phi_{i}^{\#}=\Phi_{i} \cdot E_{i}^{*}$ and the absorbed PAR by $A_{i}^{510}=300 \cdot P A R \cdot$ $\chi_{a p h}(510) \cdot a_{p h, i}(510)$. Meanwhile, the primary productivity of the total phytoplankton community $P P$ is a linear sum of those of each taxonomic group $P P_{i}$ (i.e. $P P=\sum_{i=1}^{N p} P P_{i}$ ), where $i$ is the index for

165 phytoplankton taxonomic groups and $N p$ is total number of phytoplankton groups. When diatoms are represented by $i=1$, haptophytes by $i=2$, cyanobacteria by $i=3$, and any other phytoplankton groups by $i=4$, respectively (i.e. $N_{p}=4$ ). $N$ measurements of total $P P$ allow us to establish $N$ number of $P P=$ $\sum_{i=1}^{N p} P P_{i}$ such that: 
where the vector $\boldsymbol{P P}=\left[\begin{array}{lll}P P_{n=1}, & \ldots & P P_{N}\end{array}\right]^{T}$ consists of $N$ elements (measurements) of total $P P$, and the vector $\boldsymbol{\Phi}_{i}^{\#}=\left[\begin{array}{lll}\Phi_{i=1}^{\#} & \ldots & \Phi_{i=3}^{\#}\end{array}\right]^{T}$ has three elements consisting of a $\Phi_{i}^{\#}$ value for diatoms, haptophytes and cyanobacteria, respectively. The vector $\boldsymbol{\epsilon}_{\boldsymbol{p p}}=\left[\begin{array}{lll}P P_{i=4, n=1} & \ldots \quad P P_{i=4, n=N}\end{array}\right]^{T}$ contains

$175 N$ elements, consisting of $P P$ of any phytoplankton groups $(i=4)$ other than those mentioned above. Finally, the matrix $\boldsymbol{A}=\left[\begin{array}{ccc}A_{i=1, n=1}^{510} & \cdots & A_{i=3, n=1}^{510} \\ \vdots & \ddots & \vdots \\ A_{i=1, n=N}^{510} & \cdots & A_{i=3, n=N}^{510}\end{array}\right]$ has $N \times 3$ elements consisting of $N$ number of $A_{i}^{510}$ for the three taxonomic groups (diatoms, haptophytes and cyanobacteria). When $\boldsymbol{P P}$ and $\boldsymbol{A}$ are known, Eq. (3) can be solved to obtain $\boldsymbol{\Phi}_{i}^{\#}$ as the least square solution $\boldsymbol{\Phi}_{i}^{\#}=\left(\boldsymbol{A}^{\boldsymbol{T}} \boldsymbol{A}\right)^{-1} \boldsymbol{A}^{\boldsymbol{T}} \boldsymbol{P} \boldsymbol{P}$, where $\left(\boldsymbol{A}^{\boldsymbol{T}} \boldsymbol{A}\right)^{-1}$ is the inverse of the matrix $A^{T} A$. While the primary production of total phytoplankton community can be obtained using satellite data (Behrenfeld et al., 2005; Westberry et al., 2008), determination of the matrix of the absorbed PAR $\boldsymbol{A}$ requires $\chi_{a p h}(510)$, PAR and $a_{p h, i}(510)$. We use the value 0.949 for $\chi_{a p h}(510)$ in the virtue of its quasi-constant characteristic. Satellite data of PAR is also available (e.g. Frouin et al., 2012). Hence, only $a_{p h, i}(510)$ needs to be known. Sections 2.2.2 explains how to obtain $a_{p h, i}(510)$. Once $a_{p h, i}(510)$ is derived, $\boldsymbol{A}$ will be known. Using $\boldsymbol{A}$ and $\boldsymbol{P} \boldsymbol{P}, \boldsymbol{\Phi}_{\boldsymbol{i}}^{\#}$ can be derived with

185 Eq. (3), with which the group-specific primary production for diatoms, haptophytes and cyanobacteria is finally obtained by Eq. (2).

Hereafter, the quantum yield index $\Phi_{i}^{\#}$ will be invoked to represent $\Phi_{i}$ or the state of the photophysiology of each phytoplankton group, even though $\Phi_{i}^{\#}\left(=\Phi_{i} \cdot E_{i}^{*}\right)$ is not precisely the same quantities as $\Phi_{i}$. We will also invoke $a_{p h, i}(510)$ to represent the group-specific Chla biomass due to

190 the tight correlation between $a_{p h}(510)$ and Chla found in the local and global data $\left(\mathrm{r}^{2}=0.90, \mathrm{p}<\right.$ $0.001)$, despite the fact that $510 \mathrm{~nm}$ is located within a carotenoid absorption band(s) rather than a chlorophyll absorption band.

\subsubsection{Derivation of the taxon-specific absorption coefficient}

195

By definition, $a_{p h}(510)$ is a sum of $a_{p h, i}(510)$ such that 
200 where $a_{p h, i}^{*}(510)$ is the chlorophyll $a$ specific absorption coefficient for each phytoplankton group defined as $a_{p h, i}^{*}(510)=a_{p h, i}(510) / C h l a_{i}$. In the manner similar to formulating Eq. (3), $N$ measurements of $a_{p h}(510)$ allows us to establish $N$ number of Eq. (4) such that

$a_{p h}^{510}=\operatorname{Chla}_{i} a_{p h, i}^{* 510}+\epsilon_{a p h}$

where $\boldsymbol{a}_{\boldsymbol{p h}}^{\mathbf{5 1 0}}=\left[\begin{array}{lll}a_{p h}(510)_{n=1} & \ldots & a_{p h}(510)_{N}\end{array}\right]^{T}$ consists of $N$ elements of $a_{p h}(510), \boldsymbol{a}_{\boldsymbol{p h}, \boldsymbol{i}}^{* \mathbf{5 1 0}}=$ $\left[\begin{array}{lll}a_{p h, i=1}^{* 510}, & \ldots, & a_{p h, i=3}^{* 510}\end{array}\right]^{T}$ is a 3 -element vector consisting of $a_{p h, i}^{*}(510)$ for daiatoms, haptophytes and cyanobacteria, $\boldsymbol{\epsilon}_{\boldsymbol{a p h}}=\left[a_{p h, i=4}(510)_{n=1}, \quad \ldots, \quad a_{p h, i=4}(510)_{n=N}\right]^{T}$ consists of $N$ elements of $a_{p h, i}(510)$ of any other phytoplankton groups $\left(a_{p h, 4}(510)\right)$ and the matrix

$\boldsymbol{C h l a}_{i}=\left[\begin{array}{ccc}\text { Chla }_{i=1, n=1} & \cdots & \text { Chla }_{i=3, n=1} \\ \vdots & \ddots & \vdots \\ \text { Chla }_{i=1, n=N} & \cdots & \text { Chla }_{i=3, n=N}\end{array}\right]$ has $N \times 3$ elements consisting of $N$ number of Chla $_{i}$ for diatoms, haptophytes and cyanobacteria (i.e. $\mathrm{N}$ x 3 elements). Equation (5) can be solved to obtain

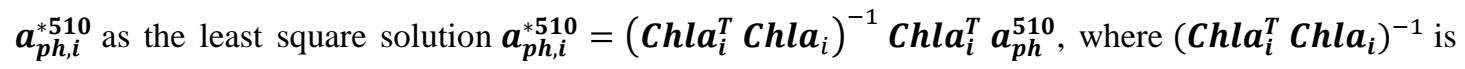
the inverse of the matrix $\boldsymbol{C h l a} \boldsymbol{T} \boldsymbol{C} \boldsymbol{C h l a} \boldsymbol{a}_{\boldsymbol{i}}$. The solution requires $a_{p h}(510)$ and $C h l a_{i}$ to be known. Both can be obtained as satellite data (e.g., Lee et al., 2002, Smyth et al., 2006, Werdell et al., 2013, Bracher

215 et al., 2009, Hirata et al., 2011, Sadeghi et al., 2012). As a result, $\boldsymbol{a}_{\boldsymbol{p h}, \boldsymbol{i}}^{* 510}$ can be obtained. Once $\boldsymbol{a}_{\boldsymbol{p h}, \boldsymbol{i}}^{* 510}$ is derived, we can find $a_{p h, i}(510)$ for diatoms, haptophytes and cyanobacteria as an element of the vector $\boldsymbol{C h l a} \boldsymbol{a}_{\boldsymbol{p h}, \boldsymbol{i}}^{* \mathbf{5 1 0}}$. The resulting $a_{p h, i}(510)$ is then used to obtain the matrix $\boldsymbol{A}$ for determining $\boldsymbol{\Phi}_{i}^{\#}$ by Eq. (3), hence determining $\boldsymbol{P P}_{i}$ eventually.

\subsubsection{Spatial data sub-sampling}

Eqs. (3) and (5) cannot be preformed for each grid or pixel in a satellite image because only one value is available at each pixel for each input variable (e.g., only one value of $C h l a_{i}$ is available for (x, y), 
Biogeosciences Discuss., doi:10.5194/bg-2017-164, 2017

Manuscript under review for journal Biogeosciences

Discussion started: 8 May 2017

(c) Author(s) 2017. CC-BY 3.0 License.

where $\mathrm{x}$ and $\mathrm{y}$ represent the longitudinal and latitudinal coordinates, respectively). However, they are

solvable when $N$ number of neighboring pixels are used. By defining a geographically small region (or "window") consisting of $N=n \times n$ neighboring pixels in a satellite image of each input variable (i.e. $N=n^{2}$ satellite data samples are contained in the window), we can sub-sample the satellite data from the window to collect $N$ measurements. We selected $n=5$ (i.e. $N=5 \times 5=25$ pixels) for a square window in the present analysis in order to achieve a balance between the statistical robustness of the regression and the resulting degradation of the spatial resolution that was tolerable for our later analysis. With $n=5$, the system of the simultaneous equations (i.e. Eq. (5)) established for the window is usually overdetermined as there are only three unknowns (i.e. $a_{p h, i}^{*}(510)$ for the three phytoplankton groups). Hence, the system is solved by the least square method. One value of $a_{p h, i}^{*}(510)$ of each phytoplankton group (3 groups in our case) is then obtained for that window. By repeating this operation for neighboring windows within the same satellite image, one can obtain a map of $a_{p h, i}^{*}(510)$ as a collection of output values from these windows, although the output images from this procedure has less spatial resolution than those of the input variables. Once $a_{p h, i}^{*},(510)$ is derived, $a_{p h, i}(510)$ is obtained, too, by multiplying $a_{p h, i}^{\prime \prime}(510)$ by $C h l a_{i}$. Using $a_{p h, i}(510)$, the similar procedure is repeated with Eq. (3), which then gives a map of $\Phi_{i}^{\#}$, hence of $P P_{i}$, for the 3 groups.

We further repeat these operations for monthly images to generate a monthly time series of the derived variables $\left(a_{p h, i}^{*}(510), a_{p h, i}(510), \Phi_{i}^{\#}\right.$, and $\left.P P_{i}\right)$ for the period of 1998-2007, from which monthly climatological data is obtained. Note that, for each window, a correction of the degree of freedom may be required in the regression analysis when a significant spatial autocorrelation among data samples within a window of an input variable(s) is found. Also note that the degree of tolerable

245 degradation of spatial resolution of derived quantities is application-specific, and one may change the window size as appropriate.

As a result, the integration of the bio-optical theory and the multi-pixel image processing enables the derivation of the biological quantities $a_{p h, i}^{*}(510), a_{p h, i}(510), \Phi_{i}^{\#}$, and $P P_{i}$ for each phytoplankton group considered here.

\subsubsection{Evaluation of the relative impact of $a_{p h, i}(510)$ and $\Phi_{i}^{\#}$ on $\boldsymbol{P P}_{i}$}


Biogeosciences Discuss., doi:10.5194/bg-2017-164, 2017

Manuscript under review for journal Biogeosciences

Discussion started: 8 May 2017

(c) Author(s) 2017. CC-BY 3.0 License.

Multiple linear regression analysis was performed between the dependent variable $P P_{i}$ and the independent variables $a_{p h, i}(510)$ and $\Phi_{i}^{\#}$ using their monthly climatology over 1997-2007. All

255 variables were standardized (i.e. a mean value was subtracted from the original data, and a resultant value was divided by the standard deviation) prior to the regression analysis. The analysis was performed using spatial data within the Kuroshio region for each month. The multiple linear regression coefficients for the standardized $a_{p h, i}(510)$ and $\Phi_{i}^{\#}$ were defined as their contributions to $P P_{i}$, and seasonal variation of the contributions was evaluated for each taxonomic group.

\section{Results}

\subsection{Spatial distribution of the group-specific characteristics associated with primary production in the Kuroshio region}

Figure 4 shows the climatological distribution of the absolute abundance of Chla $a_{i}$ the relative abundance of $C h l a_{i}, a_{p h, i}(510), a_{p h, i}^{*}(510), \Phi_{i}^{\#}$, and $P P_{i}$ of the three taxonomic groups for the period of 1998-2007. The climatological average of the absolute abundance of Chla $a_{i}$ of diatoms, haptophytes, and cyanobacteria of the entire region defined in our analysis were $0.21 \mathrm{mg} \mathrm{Chl} \mathrm{m} \mathrm{m}^{-3}, 0.11 \mathrm{mg} \mathrm{Chla} \mathrm{\textrm {m } ^ { - }}$


defined, we found the clear tendency that the diatom- and haptophyte-derived Chla $a_{i}$ were higher on the northern side of the Kuroshio Current. Conversely, cyanobacterium-derived Chla $a_{i}$ were rather uniform over the region.

The spatial pattern of $a_{p h, i}(510)$ was similar to that of Chla for all three phytoplankton 275 groups (Figs. 4a-c and $4 \mathrm{~g}-\mathrm{i}$ ); therefore, $a_{p h, i}(510)$ can be used to represent the Chla in the Kuroshio region even if $510 \mathrm{~nm}$ is out of chlorophyll a absorption bands. The climatological 10-year averages (1998-2007) of $a_{p h, i}(510)$ for diatoms, haptophytes, and cyanobacteria were $0.0016 \mathrm{~m}^{-1}, 0.0026 \mathrm{~m}^{-1}$, and $0.0012 \mathrm{~m}^{-1}$, respectively, indicating that haptophytes are more abundant over this region.

The relative abundance of diatoms also showed a similar spatial pattern to Chla. However, 280 haptophytes and cyanobacteria did not. Haptophytes exhibited a higher relative abundance along the Kuroshio Current (Fig. 4e), while cyanobacteria did so on the southern side of the Kuroshio Current (Fig. 4f) (see Fig. 1 also). The climatological averages of the relative abundances of diatoms, 
Biogeosciences Discuss., doi:10.5194/bg-2017-164, 2017

Manuscript under review for journal Biogeosciences

Discussion started: 8 May 2017

(c) Author(s) 2017. CC-BY 3.0 License.

haptophytes, and cyanobacteria over the region were $18 \%, 30 \%$, and $17 \%$, respectively, indicating again that haptophytes are the most dominant group in the region

The climatological regional averages of $a_{p h, i}^{*}(510)$ for diatoms, haptophytes, and cyanobacteria were $0.016 \mathrm{~m}^{2} \mathrm{mg} C h l a^{-1}, 0.027 \mathrm{~m}^{2} \mathrm{mg} \mathrm{Chla}{ }^{-1}$, and $0.040 \mathrm{~m}^{2} \mathrm{mg} \mathrm{Chla}$, respectively. The magnitude of $a_{p h, i}^{*}(510)$ for diatoms was smaller than that for cyanobacteria over the entire region, while the magnitude of $a_{p h, i}^{*}(510)$ for haptophytes fell between those two values. The geographical variability in $a_{p h, i}^{*}(510)$, defined here as the coefficient of variation, $\sigma_{a p h * i(510)} /$ $\overline{a_{p h}^{*}(510)}$, where $\sigma_{a p h, i(510)}$ is the standard deviation of $a_{p h, i}^{*}(510)$, was higher for cyanobacteria than diatoms in the climatological field $(0.10,0.15$, and 0.16 for diatoms, haptophytes, and cyanobacteria, respectively). An elevated value of $a_{p h, i}^{*}(510)(>0.05)$ was observed along the Kuroshio Current for cyanobacteria (Fig. 4i). Haptophytes showed a spatial pattern of $a_{p h, i}^{*}(510)$ similar to that of $C h l a_{i}$, whereas diatoms showed a relatively uniform spatial pattern of $a_{p h, i}^{*}(510)$

295 than those of haptophytes and cyanobacteria.

The spatial distribution of $\Phi_{i}^{\#}$ was classified into two patterns for the three phytoplankton groups. The diatom-derived $\Phi_{i}^{\#}$, with a climatological regional average of $0.8 \times 10^{-3}$, was higher on the southern side of the Kuroshio Current $\left(\sim 0.2 \times 10^{-2}\right)$ than on the northern side $\left(<0.1 \times 10^{-2}\right)$. The haptophyte-derived $\Phi_{i}^{\#}$ had a similar pattern to that of the diatoms but was relatively more uniform over the region with a climatological regional average of $0.2 \times 10^{-3}$. Conversely, the cyanobacteriumderived $\Phi_{i}^{\#}$ (climatological regional average of $0.2 \times 10^{-3}$ ) was to some extent higher on the northern side $\left(\sim 0.5 \times 10^{-3}\right)$ of the Kuroshio Current than on the southern side $\left(\sim 0.2 \times 10^{-3}\right)$, contrasting with the spatial patterns of the diatom- and haptophyte-derived $\Phi_{i}^{\#}$.

The climatological regional averages of $P P_{i}$ for diatoms, haptophytes, and cyanobacteria were

$305134 \mathrm{mg} \mathrm{C} \mathrm{m}^{-2}$ day $^{-1}, 72 \mathrm{mg} \mathrm{C} \mathrm{m}^{-2}$ day $^{-1}$, and $40 \mathrm{mg} \mathrm{C} \mathrm{m}^{-2}$ day $^{-1}$, respectively. The values of $P P_{i}$ showed a clear latitudinal gradient for all groups such that they were higher at higher latitudes and lower at lower latitudes. However, the gradient was largest for diatoms and smallest for cyanobacteria. The latitudinal gradient of $P P_{i}$ was therefore in agreement with $C h l a_{i}$ for diatoms but not necessarily so for cyanobacteria. As a result, the diatom-derived $P P_{i}$ had a spatial pattern very different from that of the diatom-derived $\Phi_{i}^{\#}$, whereas the cyanobacterium-derived $P P_{i}$ had a pattern closer to that of the cyanobacterium-derived $\Phi_{i}^{\#}$. 
Biogeosciences Discuss., doi:10.5194/bg-2017-164, 2017

Manuscript under review for journal Biogeosciences

Discussion started: 8 May 2017

(c) Author(s) 2017. CC-BY 3.0 License.

\subsection{Factors controlling group-specific primary production: which is more important, chlorophyll} $a$ biomass or physiology?

Figure 5 shows the relative contribution of variability in the group-specific phytoplankton abundance represented by $a_{p h, i}(510)$ and the photophysiology represented by $\Phi_{i}^{\#}$ to the variability in $P P_{i}$. The contribution of the abundance and photophysiology were not equal in general and depended on the taxonomic group and the season. For diatoms, the contribution of the abundance to $P P_{i}$ was always larger than that of the photophysiology. The abundance contribution for diatom $P P_{i}$ was larger than the physiological contribution throughout the year and was particularly large between May and November (0.77-0.85) compared to between December and April (0.38-0.64). Conversely, the photophysiological contribution to $P P_{i}$ if diatoms were small or even absent over the all seasons (0-0.24). In general, diatom $P P_{i}$ was derived by the abundance. For haptophytes, the physiological contribution remained large throughout the year, with a relatively smaller contribution ( 0.58) in boreal summer (JuneSeptember) and a relatively larger contribution ( 0.89) in winter (November-April). Conversely, the abundance contribution was highest (0.65) in June and lowest (0.25) in January. Thus, the two contributions were out of phase for haptophytes; however, this does not indicate a simple alternation between the abundance and physiological contributions over the year. Both the abundance and

330 physiological contributions were found significant from May to November, whereas the physiological contribution dominated from December to April. For cyanobacteria, the physiological contribution always prevailed throughout the year $(>0.65)$, while a biomass contribution was also found, but only to a small degree $(<0.26)$.

\section{Discussion}

The highest climatological regional average of primary production was found for diatoms in the entire Kuroshio region $\left(134 \mathrm{mg} \mathrm{C} \mathrm{m}^{-2}\right.$ day $^{-1}, 72 \mathrm{mg} \mathrm{C} \mathrm{m}^{-2}$ day $^{-1}$, and $40 \mathrm{mg} \mathrm{C} \mathrm{m}^{-2}$ day $^{-1}$ for diatoms, haptophytes, and cyanobacteria, respectively). However, within the Kuroshio Current and its extension domain (the area between two dotted curves in Fig. $4 p$ and $4 q$ ), the $P P_{i}$ for haptophytes was found to be higher than that for diatoms. Even though a direct validation of the satellite estimate of $P P_{i}$ remains to be conducted, a recent in situ observation by Nishibe et al. (2015) within the Kuroshio domain showed that smaller phytoplankton $(<10 \mu \mathrm{m})$ have higher production $\left(61-185 \mathrm{mg} \mathrm{C} \mathrm{m}^{-2} \mathrm{day}^{-1}\right)$ than larger 
Biogeosciences Discuss., doi:10.5194/bg-2017-164, 2017

Manuscript under review for journal Biogeosciences

Discussion started: 8 May 2017

(c) Author(s) 2017. CC-BY 3.0 License.

phytoplankton $(>10 \mu \mathrm{m})\left(82-871 \mathrm{mg} \mathrm{C} \mathrm{m}^{-2}\right.$ day $\left.^{-1}\right)$. In addition, independent in situ measurements of

molecular analyses using an Ion Torrent high-throughput sequencer indicated an elevated diversity of haptophytes in the upstream Kuroshio Current (Suzuki et al., unpublished data). An additional calculation via light microscopy in the Kuroshio Current also found that haptophytes were most closely associated with the Kuroshio front itself (Clayton et al., 2014). Our analysis is consistent with in situ studies, both in identifying the taxonomic group and for estimating the corresponding $P P_{i}$ simultaneously with a larger geographical coverage.

A high abundance of cyanobacteria was also reported by means of a cell count on the southern edge (sub-tropical side) of the Kuroshio front (Clayton et al., 2014). However, our estimates of the cyanobacterium-derived $P P_{i}$ may only be comparable to the haptophyte-derived $P P_{i}$ and may not be dominant. While the temporal and spatial scales between their analysis and ours are different, the gap can be explained by our finding that the cyanobacteria $P P_{i}$ were regulated by their photophysiology rather than their abundance. Although phytoplankton community structure is not explicitly resolved, Behrenfeld et al. (2005) showed from a satellite data analysis a less co-variation or even a decoupling between phytoplankton biomass and chlorophyll concentration in oceanic regions where chlorophyll variance is small (i.e. sub-tropical waters). In addition, White et al. (2015) showed from field

360 observations that the HPLC-based abundance of phytoplankton groups in the subtropical North Pacific was not significantly correlated with the primary productivity in the upper layers of the ocean when picoplankton was dominant, suggesting a potential role of photophysiology on $P P$. We conclude that our methodology and analysis captured the major mechanism contributing to $P P$ in the study area.

Of the quantities obtained using the presented approach, only $\Phi_{i}^{\#}$ does not precisely equal the

365 definition of the variable it was meant to represent (i.e., the quantum yield of photosynthesis). Even though $\Phi_{i}^{\#}$ was designed to represent $\Phi_{i}$, it is only an index of $\Phi_{i}$. The treatment of the numerical value of $\Phi_{i}^{\#}$ requires care, especially when it is compared with $\Phi_{i}$ values obtained from other studies. In addition, $\Phi_{i}$ is defined here for carbon fixation not for oxygen evolution. The climatological regional averages of the derived $\Phi_{i}^{\#}$ were $0.8 \times 10^{-3}, 0.2 \times 10^{-3}$, and $0.2 \times 10^{-3}$ for diatoms, 370 haptophytes, and cyanobacteria, respectively (Fig. 4m-o). Conversely, the maximum quantum yield of carbon fixation for micro-, nano-, and picoplankton for the surface layer of other oceanic domains, determined from in situ databases, were reported as $46-88 \times 10^{-3}, 7-47 \times 10^{-3}$, and 4-25 $\times 10^{-3}$, respectively (Cleveland et al., 1989; SooHoo et al., 1987; Uitz et al., 2008; Lindley et al., 1995). Therefore, our $\Phi_{i}^{\#}$ and the reported quantum yield, as expected, differ from these over two orders of 
Biogeosciences Discuss., doi:10.5194/bg-2017-164, 2017

Manuscript under review for journal Biogeosciences

Discussion started: 8 May 2017

(c) Author(s) 2017. CC-BY 3.0 License.

magnitude. Because $\Phi_{i}^{\#}=\Phi_{i} \cdot E_{i}^{*}$, this difference is attributed to $E_{i}^{*}$. For illustration only, the value of $E_{i}^{*}$ obtained from NOMAD yields approximately 1/100 over the PAR waveband (i.e. 400-700nm). The division of $\Phi_{i}^{\#}$ by $1 / 100$ (or multiplying $\Phi_{i}^{\#}$ by 100 ) would result in $80 \times 10^{-3}, 20 \times 10^{-3}$, and $20 \times 10^{-3}$ for diatoms, haptophytes, and cyanobacteria, which are in consistent with the previous reports mentioned above. In addition, the general tendency of our result, that $\Phi_{i}^{\#}$ of diatoms is higher while $\Phi_{i}^{\#}$ of cyanobacteria is lower, was also in consistent with Claustre et al. (2005). We conclude that our $\Phi_{i}^{\#}$ captured the nature of the quantum yield of photosynthesis both quantitatively and qualitatively.

Figure 4 demonstrated that there is large geographical variability in $\Phi_{i}^{\#}$ even within a single taxonomic group. Our result showed that cyanobacteria had lower $\Phi_{i}^{\#}$ in the subtropical waters south of the Kuroshio Current and higher $\Phi_{i}^{\#}$ in the subarctic waters. Cyanobacteria are known to have higher contents of zeaxanthin (Suzuki et al., 2015) that can dissipate excessively absorbed light energy to protect the photosynthetic apparatus from photooxidation due to over-excitation (Dall'Osto et al., 2012). The dissipation of the absorbed light energy results in less effective photosynthesis per unit mole of photons absorbed, leading to a smaller quantum yield at lower latitudes where light is usually not limited. This scenario may explain our result for cyanobacterium- $\Phi_{i}^{\#}$.

Class-dependent variation was found in the $a_{p h, i}^{*}(510)$ derived from the satellite observations such that diatoms (cyanobacteria) have lower (higher) $a_{p h, i}^{*}(510)$ values, whereas haptophytes have an intermediate value. This result agrees with both theory (Morel and Bricaud, 1981) and observations for size-fractionated $a_{p h}^{*}(510)$ for microplankton, nanoplankton, and picoplankton (Ciotti et al., 2002). In situ observations (the NOMAD dataset) indicate that the total $a_{p h}^{*}(510)$ is significantly correlated with the total Chla at a global scale $\left(\mathrm{r}^{2}=0.60, \mathrm{p}<0.001\right.$, in log scale), despite that it is already divided by Chla by definition, (i.e., $\left.a_{p h}^{*}=a_{p h}(510) / C h l a\right)$. This correlation not only indicates a non-linearity between $a_{p h}(510)$ and Chla but also implies a correlation between $a_{p h}(510)$ and $a_{p h}(\lambda)$ in the chlorophyll $a$ absorption bands. Indeed, $a_{p h}(510)$ were significantly correlated with $a_{p h}(670)\left(\mathrm{r}^{2}=\right.$ $0.90, \mathrm{p}<0.001)$ and $a_{p h}(443)\left(\mathrm{r}^{2}=0.99\right.$ and $\left.\mathrm{p}<0.001\right)$. Given that the wavelength of $510 \mathrm{~nm}$ falls in a

400 carotenoid absorption band, it indirectly suggests that the carotenoids and Chla are correlated at larger scales, at least to the first order. As a result, $a_{p h}^{*}(510)$ still carries information of Chla. Because Chla (and $a_{p h}(443)$ ) is known to contain information concerning the phytoplankton community structure at larger scales (e.g. Uitz et al., 2006; Hirata et al., 2008, Brewin et al., 2010, 2011), so does $a_{p h}^{*}(510)$, 
Biogeosciences Discuss., doi:10.5194/bg-2017-164, 2017

Manuscript under review for journal Biogeosciences

Discussion started: 8 May 2017

(c) Author(s) 2017. CC-BY 3.0 License.

which would partly explain its class-dependent variations. However, a care must be taken that smaller

Variability in $a_{p h}^{*}(\lambda)$ has often been attributed to a phytoplankton community change in association with the cell size via the packaging effect, which is the basis to estimate phytoplankton in different size classes (e.g., Ciotti and Bricaud, 2006; Mouw and Yoder, 2010). Because the package effect is a function of the optical thickness of a cell (i.e. the product between the cell size and the cell matter absorption including intercellular Chla (Morel and Bricaud, 1981), not only physical effects of cell size but also the intercellular Chla abundance results in the package effect. It has been reported that higher bulk Chla was observed as larger cells become more abundant (e.g., Suzuki et al., 2011). When there is a correlation between the cell size and the cellular abundance of Chla, the indirect effect of cell size on $a_{p h}^{*}(\lambda)$ via the cellular abundance of Chla is also a source of variation in the package effect.

415 Provided that the total Chla in bulk water is a simple sum of the cellular Chla of the individual cells, the relationship between the bulk Chla and the phytoplankton size structure (Hirata et al., 2011) is partly a reflection of the relationship between $a_{p h}^{*}(\lambda)$ and the community structure.

According to the mean theorem of integration, there must be at least one wavelength $\lambda^{\prime}$ where $\overline{a_{p h}(\lambda)}=a_{p h}\left(\lambda^{\prime}\right)$. We found that $\chi_{a p h}(510)$ was numerically close to unity, not only for the Kuroshio region (0.972) but also in other oceans (see section 2.2.1); therefore, $510 \mathrm{~nm}$ is often likely to be one of the $\lambda^{\prime}$, even though it may not always be the case because $\chi_{a p h}(510)$ does have variability as expressed by the CV. SeaWiFS had a waveband that has the central wavelength of $510 \mathrm{~nm}$. However, subsequent satellite instruments, such as MODIS onboard AQUA and VIIRS on Suomi NPP abandoned it. It is desirable to include the band in future satellite instruments.

We showed that the wavelength of $510 \mathrm{~nm}$ is not only equivalent to $\overline{a_{p h}(\lambda)}$ but also often a hinge point of the (inverse of) the normalized $a_{p h}(\lambda)$ spectra, $\left[a_{p h}(\lambda) / \overline{\left[a_{p h}(\lambda)\right.}\right]^{-1}=\overline{a_{p h}(\lambda)} / a_{p h}(\lambda)$. In situ Rrs can also exhibits a hinge point at the wavelength of 490- $520 \mathrm{~nm}$ (Reynolds et al. 2001). Although Rrs spectrum, hence emergence of the hinge point as well as the wavelength at which the hinge point appears, is a result of inter-play among any optical constituents responsible for the spectra (e.g. colored dissolved organic matter, inorganic particles etc.), the hinge point at $510 \mathrm{~nm}$ in the $a_{p h}(\lambda)$ spectra raises the speculation that the hinge point of the normalized $a_{p h}(\lambda)$ may be a basis of the hinge point seen in Rrs, as (i) the wavelength of the hinge points are relatively close and (ii) Rrs is also a 
Biogeosciences Discuss., doi:10.5194/bg-2017-164, 2017

Manuscript under review for journal Biogeosciences

Discussion started: 8 May 2017

(c) Author(s) 2017. CC-BY 3.0 License.

normalized quantity in that it is defined by the upward radiance divided by the radiance integrated over a specific space (i.e. the downward irradiance).

The novelty of our approach is the integration of the image processing with a bio-optical model. It allows a satellite derivation of new photophysiological quantities, such as $\Phi_{i}^{\#}$ and $a_{p h, i}^{*}(510)$. As a consequence, the photophysiological and absorption properties of each phytoplankton group need not to be assumed a priori when the group-specific primary production. In satellite ocean colour remote sensing, it is known that the ocean color and bio-optics inversions are mathematically illposed problems (Sydor et al., 2004; Defoin-Platel and Chami, 2007), and the information available (i.e., spectral measurements) is usually deficient in comparison with the number of unknowns, if only multi-spectral measurements, as those taken by conventional satellite observation, are available. The presented approach attempted to find additional information by spatial sampling of input variables, taking full advantage of the simultaneous acquisition of spatial data by the satellite remote sensing.

A drawback of the presented approach is the degradation of the spatial resolution of outputs (i.e. $P P_{i}, a_{p h, i}^{*}(510)$, and $\left.\Phi_{i}^{\#}\right)$. In this study, a $5 \times 5$ window was used to derive these quantities resulting in the spatial resolution being 5-times coarser than the original satellite image of the input variables. Future ocean color satellite sensors will have finer spatial resolution than the earlier satellites used in this analysis (e.g., a nominal spatial resolution of $300 \mathrm{~m}$ was achieved by OLCI (Ocean and Land Color Instrument) onboard Sentinel-3 and $250 \mathrm{~m}$ by SGLI (Second-generation Global Imager) on GCOM-C (Global Change Observation Mission - Climate). However, it should be emphasized that a further improvement of the spatial resolution of the $P P_{i}, a_{p h, i}^{*}(510)$, and $\Phi_{i}^{\#}$, requires continuous development of advanced ocean color instruments with finer spatial resolutions, even if the spatial resolution of the satellite signal and the conventional variables, such as Chla, reach a sufficient level for the observation of pelagic oceans.

Our approach internally involves a statistical procedure (i.e., multiple linear regression analysis), and the analysis is strongly constrained by, or based on, a bio-optical principle or model. Therefore, it is not similar to the conventional "empirical" methodologies that do not necessarily involve bio-optical mechanisms in them. As a result, in theory, it is expected that our approach can be applied to larger or smaller spatial scale analyses (e.g., basin/global and local scales). However, geographical maps of the derived quantities (e.g., $\Phi_{i}^{\#}$ and $\left.a_{p h, i}^{*}(510)\right)$ tend to be spatially noisy due to the introduction of the statistical procedure. Because the spatial resolution is already reduced due to the 
Biogeosciences Discuss., doi:10.5194/bg-2017-164, 2017

Manuscript under review for journal Biogeosciences

Discussion started: 8 May 2017

(c) Author(s) 2017. CC-BY 3.0 License.

methodological principle, temporal smoothing of the derived quantities may be a better way to reduce the noise at a cost of the temporal resolution. Hence, our methodology would be more robust for climatological analyses. The Advanced Himawari Imager (AHI) on board the recently launched geostationary satellite Himawari-8 observes the ocean color every $2.5 \mathrm{~min}$ or $10 \mathrm{~min}$, depending on the focused region within the field of view. Therefore, noisy outputs are expected to improve with the high temporal frequency observations of AHI, which would allow for the application of the presented methodology at finer temporal scales. In summary, the presented approach has room to improve further via advances in the spatial and temporal resolutions of satellite observations.

\section{Conclusions}

In situ measurements of the optical absorption coefficient of phytoplankton showed that the inversed data of the normalized spectrum often exhibited a hinge point at $510 \mathrm{~nm}$ which may be a basis of a hinge point of Rrs spectra observed. In addition, the absolute magnitude (i.e. un-normalized) of the absorption coefficient at this wavelength often corresponded to the magnitude of spectral average over 400 and $700 \mathrm{~nm}$. As a result, the importance of wavelength of $510 \mathrm{~nm}$ was highlighted for ocean colour and photosynthetic study, and an inclusion of this wavelength in the future satellite and/or in situ observation mission of ocean colour was recommended.

In the virtue of the representativeness of the phytoplankton absorption coefficient at $510 \mathrm{~nm}$ as its spectral average over $400-700 \mathrm{~nm}$, and by taking advantage of spatial bulk sampling by satellite remote sensing, a proof of concept of satellite-based bio-optical inversion was provided by utilizing spatial variability in satellite-derived phytoplankton absorption data, rather than spectral variability. The new methodology demonstrated a possibility of derivation of the new satellite products such as the group-specific quantum yield index, the group- and the chlorophyll-specific absorption coefficients at $510 \mathrm{~nm}$ and the group-specific primary production. Among those quantities, the index of the quantum yield for photosynthesis was of particular importance, as it opened a door to access to photophysiological information of marine phytoplankton from space at large scales so that more direct assessment of primary production may become possible without assuming the photo-physiology.

Analysis of the satellite data of the group-specific quantum yield index and the primary production showed that variability of primary production by diatoms in the Kuroshio region was driven due to the variability of their abundance, whereas variability of the cyanobacteria production was 
Biogeosciences Discuss., doi:10.5194/bg-2017-164, 2017

Manuscript under review for journal Biogeosciences

Discussion started: 8 May 2017

(c) Author(s) 2017. CC-BY 3.0 License.

driven by physiology. In addition, the variability of haptophytes production showed comparable effects from both abundance and physiology in northern summer.

While validation of the derived quantities, as well as applicability test of the methodology to temporal/spatial scales especially smaller than those considered in our study, remains to be done. More frequent simultaneous observation of a suit of photosynthetic parameters and the ocean colour variables should be carried out.

\section{Competing interest}

The authors declare that they have no conflict of interest.

\section{Acknowledgements}

We would like to thank the NASA Ocean Biology Processing Group for their satellite (SeaWiFS) and in situ (NOMAD) data. This work was funded by The Study of Kuroshio Ecosystem Dynamics for Sustainable Fisheries and by Grants-in-Aid for Scientific Research 15K00513.

\section{References}

Barnes, M. K., Tilstone, G. H., Smyth, T. J., Suggett, D. J., Astoreca, R., Lancelot, C., and Kromkamp, J. C.: Absorption-based algorithm of primary production for total and size-fractionated phytoplankton in coastal waters. Mar. Ecol. Prog. Ser., 504, 73-89, 2014.

515 Behrenfeld , M. J., Boss, E., Siegel, D. A., and Shea, D. M.: Carbon-based ocean productivity and phytoplankton physiology, Glob. Biogeochem. Cycles, 19, GB1006, doi:10.1029/2004GB002299, 2005.

Bracher, A., Vountas, M., Dinter, T., Burrows, J. P., Röttgers, R., and Peeken, I.: Quantitative 520 observation of cyanobacteria and diatoms from space using PhytoDOAS on SCIAMACHY data, Biogeosciences, 6, 751-764, doi:10.5194/bg-6-751-2009, 2009.

Bury, S. J., Boyd, P.W., Preston, T., Savidge, G., and Owens, N. J. P.: Size-fractionated primary production and nitrogen uptake during a North Atlantic phytoplankton bloom: implications for carbon export estimates. Deep-Sea Res. I, 48, 689-720, 2001.

Carr, M.E, Friedrichs, M.A.M., Schmeltz, M., Aita, M.N., Antoine, D., Asanuma, I., Aumont, O., Barber, R., Behrendfeld, M., Buitenhuis, E.T., Campbell, J., Ciotti, A., Dierssen, H., Dowell, M., 
Biogeosciences Discuss., doi:10.5194/bg-2017-164, 2017

Manuscript under review for journal Biogeosciences

Discussion started: 8 May 2017

(C) Author(s) 2017. CC-BY 3.0 License.

Dunne, J., Esaias, W., Gentili, B., Gregg, W., Groom, S., Hoepffner, N., Ishizaka, J., Kameda, T., Le

Quéré, Lohrenz, S., Marra, J., Mélin, F., Moore, K., Morel, A., Reddy, T.E., Ryan, J., Scardi, M., Smyth, T., Turpie, K., Tilstone, G., Waters, K., Yamanaka, Y.: A comparison of global estimates of marine primary production from ocean color, Deep-Sea Res. II, 53, 741-770, 2006.

Ciotti, A. M., Lewis, M. R., and Cullen, J.: Assessment of the relationships between dominant cell size in natural phytoplankton communities and the spectral shape of the absorption coefficient, Limnol. Oceanogr., 47, 404-417, 2002.

Ciotti, A. M. and Bricaud. A.: Retrieval of a size parameter for phytoplankton and spectral absorption by colored detrital matter from water-leaving radiance at SeaWiFS channels in a continent shelf region off Brazil. Limnol. Oceanogrr., 4, 237-253, 2006.

Claustre, H., Babin, M., Merien, D., Ras, J., Prieur, L., and Dallot, S.: Toward a taxon-specific parameterization of bio-optical models of primary production: A case study in the North Atlantic. $J$. Geophys. Res., 110, C07S12, doi:10.1029/2004JC002634, 2005.

Clayton, S., Nagai, T., and Follow, M. J.: Fine scale phytoplankton community structure across the Kuroshio Front, J. Plankton Res., 36, 1017-1030, 2014.

Cleveland, J. S., Perry, M. J., Kiefer, D. A., and Talbot, M. C.: Maximum quantum yield of photosynthesis in the northwestern Sargasso Sea, J. Mar. Res, 47, 869-886, 1989.

Cleveland, J. S., and Weidemann, A.D.: Quantifying absorption by aquatic particles: A multiple scattering correction for glass-fiber filters. Limnol. Oceanogr.,. 38, 1321-1327, 1993.

555 Cushing, D. H.: A difference in structure between ecosystems in strongly stratified waters and those that are only weakly stratified. J. Plankton Res., 11, 1-14, 1989.

Dall'Osto, L., Holt, N. E., Kaligotla, S., Fuciman, M., Cazzaniga, S., Carbonera, D., Frank, H. A., Alric, J., and Bassi, R.: Zeaxanthin protects plant photosynthesis by modulating chlorophyll triplet yield in specific light-harvesting antenna subunits. J. Biol. Chem., 287, 41820-41834, 2012.

Defoin-Platel, M. and Chami, M.: How ambiguous is the inverse problem of ocean color in coastal waters? J. Geophys. Res., 112, C03004, doi:10.1029/2006JC003847, 2007.

565 Fishwick, J., Aiken, J., Barlow, R., Sessions, H., Bernard, and S., Ras, J.: Functional relationships and bio-optical properties derived from phytoplankton pigments, optical and photosynthetic parameters: a case study of the Benguela ecosystem, J. Mar. Biol. Assoc. U.K., 86, 1267-1280, 2006.

Frouin, R., McPherson, J. ,Ueyoshi, K., and Franz, B. A.: A time series of photosynthetically available 
Biogeosciences Discuss., doi:10.5194/bg-2017-164, 2017

Manuscript under review for journal Biogeosciences

Discussion started: 8 May 2017

(C) Author(s) 2017. CC-BY 3.0 License.

radiation at the ocean surface from SeaWiFS and MODIS data. Rem. Sens. Mar. Environ II, http://dx.doi.org/10.1117/12.981264, 2012.

Hirata, T., Aiken, J., Hardman-Mountford, N.J., Smyth, T. J., and Barlow, R.G.: An absorption model to determine phytoplankton size classes from satellite ocean colour, Rem. Sens. Environ., 112, 3153-

5753159,2008

Hirata, T., Hardman-Mountford, N. J. Barlow, R., Lamont, T., Brewin, R., Smyth, T. J., and Aiken, J.: (2009). An inherent optical property approach to the estimation of size-specific photosynthetic rates in eastern boundary upwelling zones from satellite ocean colour: An initial assessment. Prog. Oceanogr..,

580 1-4, 393-397, 2009.

Hirata, T., Hardman-Mountford, N. J., Brewin, R. J. W., Aiken, J., Barlow, R., Suzuki, K., Isada, T., Howell, E., Hashioka, T., Noguchi-Aita, M., and Yamanaka, Y. :(2011). Synoptic relationships between surface Chlorophyll-a and diagnostic pigments specific to phytoplankton functional types.

Biogeosciences, 8, 311-327, 2011.

Jochem, F. J., Mathot, S., and Quéguiner, B.: Size-fractionated primary production in the open Southern Ocean in austral spring. Polar Biol., 15, 381-392, 1995.

590 Kameda, T. and Ishizaka, J.: Size-fractionated primary production estimated by two-phytoplankton community model applicable to ocean color remote sensing, J. Oceanogr., 51, 663-672, 2005.

Lindley, S. T., Bidigare, R. R.,and Barber, R. T.: Phytoplankton photosynthesis parameters along 14 degree W in the Equatorial Pacific. Deep-Sea Res. II, 42, 441-463, 1995.

595

Lee, Z.P., Carder, K.L., and Arnone, R.A.: Deriving Inherent Optical Properties from Water Color: A Multiband Quasi-analytical Algorithm for Optically Deep Waters, Appl. Opt., 41, 5755-5772, 2002.

Lee, Z.P., Carder, K.L., Marra, J., Steward, R.G., Perry, M.J.: Estimating primary production at depth from remote sensing. Appl. Opt., 35, 463-474, doi:10.1364/AO.35.000463, 1996.

Marra, J., C. Trees, C., and O’Reilly, J. E.: Phytoplankton pigment absorption: A strong predictor of primary productivity in the surface ocean. Deep-Sea Res. I, 54, 155-163, 2007.

605 Mann, K., H. and Lazier, J. R. N.: Dynamics of Marine Ecosystems, Nova Scotia: Blackwell Publishing, 2006.

Mitchell, G., Kahru, M., Wieland, J., and Stramska, M.: "Determination of spectral absorption coefficients of particles, dissolved material and phytoplankton for discrete water samples", In: Ocean

610 Optics Protocols for Satellite Ocean Color Sensor Validation, Revision 3, Vol 2, editor. J.L. Mueller and G.S. Fargion (Greenbelt, ML: NASA), 231-257, 2000. 
Biogeosciences Discuss., doi:10.5194/bg-2017-164, 2017

Manuscript under review for journal Biogeosciences

Discussion started: 8 May 2017

(C) Author(s) 2017. CC-BY 3.0 License.

Morel, A., and Prieur, L.: Analysis of variations in ocean color. Limnol. Oceanogr., 22, 709-722, 1977.

Morel, A. and Bricaud, A : Theoretical results concerning light absorption in a discrete medium and application to specific absorption of phytoplankton. Deep-Sea Res 28A, 1375-1393, 1981.

Mouw, C. and Yoder, J. A.: Optical determination of phytoplankton size composition from global SeaWiFS imagery. J. Geophys. Res., 115 C12018, doi:10.1029/2010JC006337, 2010.

Morán, X.A.G., Fernández, E., and Peréz, V.: Size-fractionated primary production, bacterial production and net community production in subtropical and tropical domains of the oligotrophic NE Atlantic in autumn. Mar. Ecol. Prog. Ser., 274, 17-29, 2004.

Nagai, T., Yamazaki, H., and Kamykowski, D. A.: Lagrangian photoresponse model coupled with $2^{\text {nd }}-$ order turbulence closure. Mar. Ecol. Prog. Ser., 265, 17-30, 2012.

Nishibe, Y., Takhashi, K., Shiozaki, T., Kakehi, S., Saitoh, H., and Furuya, K.: Size-fractionated primary production in the Kuroshio Extension and adjacent regions in spring, J. Oceanogr., 71, 27-40, 2015.

630 O’Reilly, J. E., Maritorena, S., Mitchell, B.G., Siegel, D. A., Carder, K.L., Garver, S. A., Kahru, M., and McClain, C.: Ocean color chlorophyll aogorithm for SeaWiFS. J. Geophys. Res., 103, $24937-$ 24953, 1998.

Owens, N. J. P., Burkill, P. H., Mantoura, R. F. C., Woodward, E. M. S., Bellan, I. E., Aiken, J.,

635 Howland, R. J. M., and Llewellyn, C. A.: Size-fractionated primary production and nitrogen assimilation in the northwestern Indian Ocean. Deep-Sea Res. II, 40, 697-709, 1993.

Pikitch, E. K., Santora, C., Babcok, E. A., Bakun, A., Bonfil, R., Conover, D. O., Dayton, P., Doukakis, P., Fluharty, D., Heneman, B., Houde, E. D., Link, J., Livingston, P. P., Mangel, M.,

640 McAllister, M. K., Pope, J., and Sainsbury, K. J.: Ecosystem-based fisheries management. Science, 305, 346-347, 2004.

Reynolds, R. A., Stramski, D., Mitchell, B. G.: A chlorophyll-dependent semianalytical reflectance derived from field measurements of absorption and backscattering coefficients within the Southern Ocean, J. Geophys. Res., 106, 7125-7138, 2001.

Robinson, C.M., Cherukuru, N., Hardman-Mountford, N.J., Everett, J.D., McLaughlin, M.J., Davies, K.P., Van Dongen-Vogels, V., Ralph, P.J., and Doblin, M.A.: Phytoplankton absorption predicts patterns in primary productivity in Australian coastal shelf waters, Estuarine, Coastal and Shelf

650 Science, doi:10.1016/j.ecss.2017.04.012, 2017.

Sadeghi, A., Dinter, T., Vountas, M., Taylor, B., Altenburg-Soppa, M., and Bracher, A.: Remote sensing of coccolithophore blooms in selected oceanic regions using the PhytoDOAS method applied 
Biogeosciences Discuss., doi:10.5194/bg-2017-164, 2017

Manuscript under review for journal Biogeosciences

Discussion started: 8 May 2017

(C) Author(s) 2017. CC-BY 3.0 License.

to hyper-spectral satellite data, Biogeosciences, 9, 2127-2143, doi:10.5194/bg-9-2127-2012, 2012.

Sassa, C., Kawaguchi, K., Hirota, Y., and Ishida, M.: Distribution patterns of larval myctophid fish assemblages in the subtropical-tropical waters of the western North Pacific. Fish. Oceanogr., 13, 267$282,2004$.

660 Smyth, T. J., Moore, G. F., Hirata, T., and Aiken, J.: Semianalytical model for the derivation of ocean color inherent optical properties: description, implementation, and performance assessment. App. Opt., 45, 8116-8131, 2006.

SooHoo, J. B., Palmisano, A. C., Kottmeier, S. T., Lizotte, M. P., SooHoo, S. L., and Sullivan, C.W.:

665 Spectral light absorption and quantum yield of photosynthesis in sea ice microalgae and a bloom of Phaeocystis pouchetii from McMurdo Sound, Antarctica. Mar. Ecol. Prog. Ser., 39, 175-189, 1987.

Suzuki, K., Kuwata, A., Yoshie, N., Shibata, A., Kawanobe, K., and Saito, H.: Population dynamics of phytoplankton, heterotrophic bacteria, and viruses during the spring bloom in the western subarctic Pacific. Deep-Sea Res. I, 58, 575-589, 2011.

Suzuki, K., Kamimura, A., and Hooker, S. B.: Rapid and highly sensitive analysis of chlorophylls and carotenoids from marine phytoplankton using ultra-high performance liquid chromatography (UHPLC) with the first derivative spectrum chromatogram (FDSC) technique. Mar. Chem., 176, 96-109, 2015.

Sydor, M., Gould, R. W., Arnone, R. A., Haltrin, V. I., and Goode, W.: Uniqueness in remote sensing of the inherent optical properties of ocean water. Appl. Opt., 43, 2156-2162, 2004.

Uitz, J., Claustre, H., Morel, A., and Hooker, S. B.: Vertical distribution of phytoplankton communities in open ocean: An assessment based on surface chlorophyll. J. Geophys. Res., 111 C08005, doi:10.1029/2005JC003207, 2006.

Uitz, J., Huot, Y., Bruant, F., Babin, M., and Claustre, H.: Relating phytoplankton photophysiological properties to community structure on large scales, Limnol. Oceanogr., 53, 615-630, 2008.

Uitz, J., Claustre, H., Gentili, B., and Stramski, D.: Phytoplankton class-specific primary production in the world's oceans: Seasonal and interannual variability from satellite observations, Glob. Biogeochem. Cycles, 24, 10.1029/2009GB003680. 2010.

690 Vidussi,F., Claustre, H., Manca, B.B., Luchetta, A., and Marty, J-C. : Phytoplankton pigment distribution in relation to upper thermocline circulation in the eastern Mediterranean Sea during winter, J. Geophys. Res., 106, 19939-19956, 2001.

Werdell, P. J. and Bailey, S. W.: An improved in-situ bio-optical data set for ocean colour algorithm 
Biogeosciences Discuss., doi:10.5194/bg-2017-164, 2017

Manuscript under review for journal Biogeosciences

Discussion started: 8 May 2017

(c) Author(s) 2017. CC-BY 3.0 License.

695 development and satellite data product validation. Rem. Sens. Environ., 98, 122-140, 2005.

Werdell, P. J., Franz, B.A., Bailey, S. W., Feldman, G.C., Boss, E., Brando, V. E., Dowell, M., Hirata, T., Lavender, S. J., Lee, Z.-P., Loisel, H., Maritorena, S., Melin, F., Moore, T. S., Smyth, T.J., Antoine, D., Devred, E., d'Andon, O.H.F. and M. A.: Generalized ocean color inversion model for retrieving 700 marine inherent optical properties, Appl. Opt., 52, 2019-2037, 2013.

Westeberry, T., Behrenfeld, M. J., Siegel, D. A., and Boss, E.: Carbon-based primary productivity modelling with vertically resolved photoacclimation, Glob. Biogeochem. Cycles, 22, GB2024, doi:10.1029/2007GB003078, 2008.

705

White, A. E, Leteier, R. M., Whitmire, A. L. Barone, , B., Bidigare, R. R., Church, M. J., Karl, and D. M.: Phenology of particle size distributions and primary productivity in the North Pacific subtropical gyre (Station ALOHA). J. Geophys. Res., 120, doi:10.1002/2015JC010897, 2015.

\section{Funding}

This research was supported by The Study of Kuroshio Ecosystem Dynamics for Sustainable Fisheries (SKED) funded by MEXT and in part by KAKENHI funded by JSPS (Grant Number 15K00513). 
Biogeosciences Discuss., doi:10.5194/bg-2017-164, 2017

Manuscript under review for journal Biogeosciences

Discussion started: 8 May 2017

(C) Author(s) 2017. CC-BY 3.0 License.
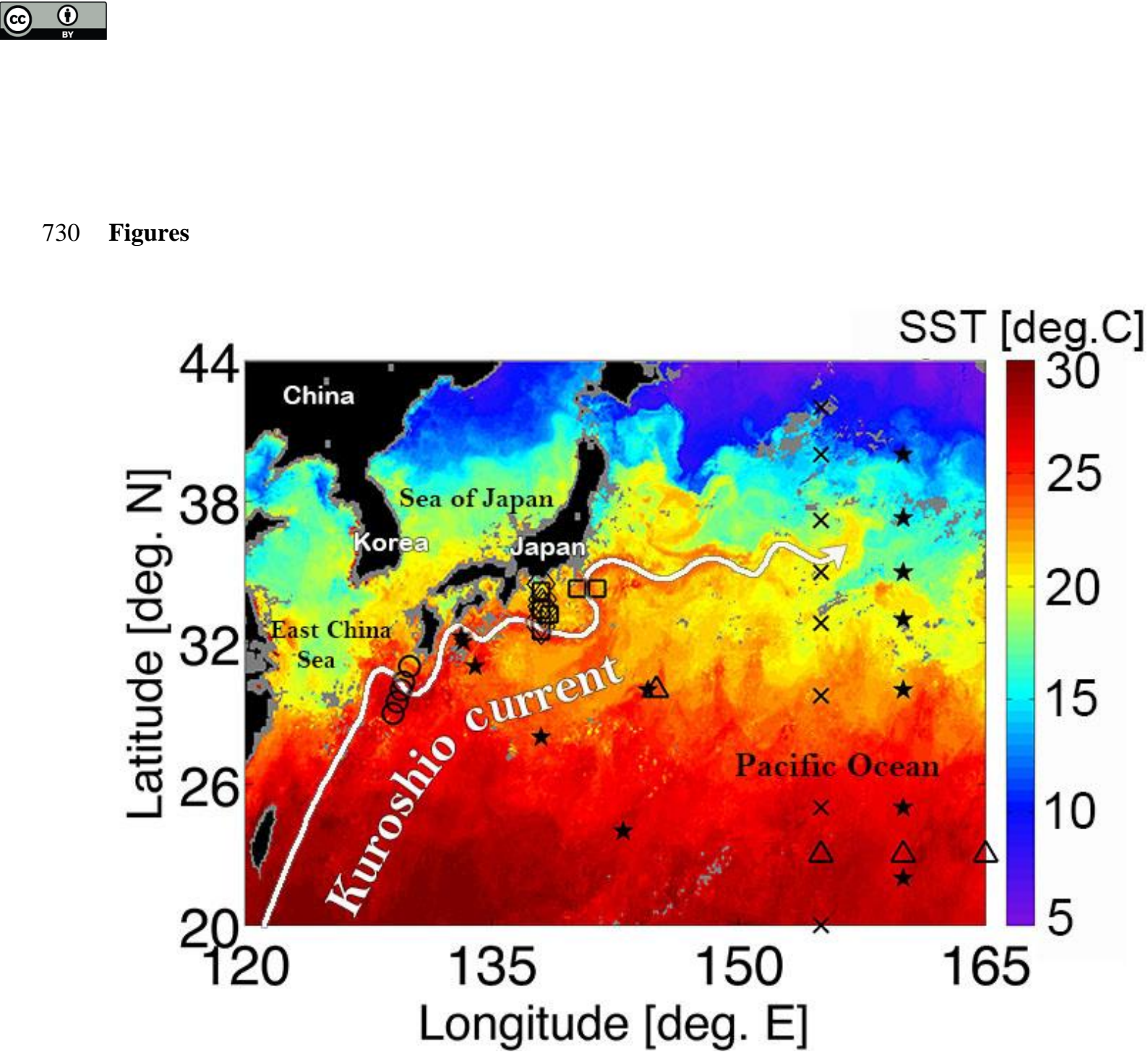

Figure 1: The Kuroshio region defined in this study $\left(120-165^{\circ}\right.$ E, 20-44 ${ }^{\circ}$ N). Symbols shows observation stations during different cruises : R/V Tansei-Maru KT-12-31 cruise, November 18-22,

7352012 (о); the R/V Soyo-Maru SY-13-04 cruise from April 16 to 25, 2013 (); the R/V Hakuho-Maru KH-08-02 cruise from August 28 to September 9, 2008 (×); the R/V Tanse-Maru KT-12-05 cruise from September 9 to 13, $2012(\diamond)$; the R/V Hakuho-Maru KH12-03 cruise from July 10 to August 11, $2012(\star)$; and the R/V Hakuho-Maru KH11-10 cruise from December 1 to 20, $2011(\triangle)$. The background color indicates the sea surface temperature (SST) on May 24-31, 2016 observed by NASA

740 MODIS Terra. The SST is shown only to provide a geographical illustration of the Kuroshio region, and there is no association of the actual SST during the observation cruise mentioned in the text. 
Biogeosciences Discuss., doi:10.5194/bg-2017-164, 2017

Manuscript under review for journal Biogeosciences

Discussion started: 8 May 2017

(c) Author(s) 2017. CC-BY 3.0 License.

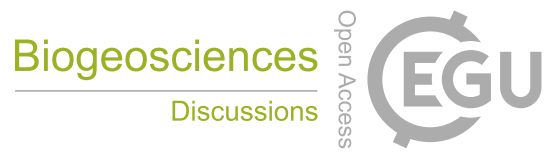

(c) (1)

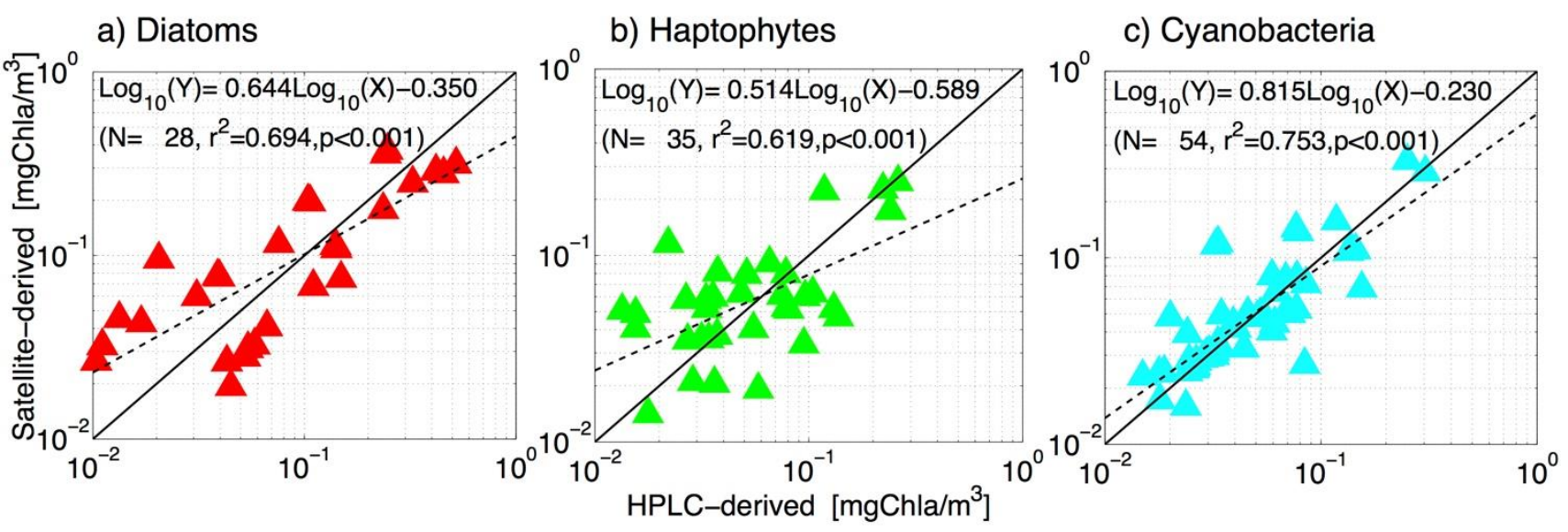

Figure 2: Calibration of the OC-PFT algorithm (Hirata et al., 2011) used to derive the group-specific chlorophyll $a$ concentration using the in situ HPLC data obtained in the Kuroshio region defined in Fig.

1: (a) diatoms, (b) haptophytes, and (c) cyanobacteria.

755 
Biogeosciences Discuss., doi:10.5194/bg-2017-164, 2017

Manuscript under review for journal Biogeosciences

Discussion started: 8 May 2017

(C) Author(s) 2017. CC-BY 3.0 License.
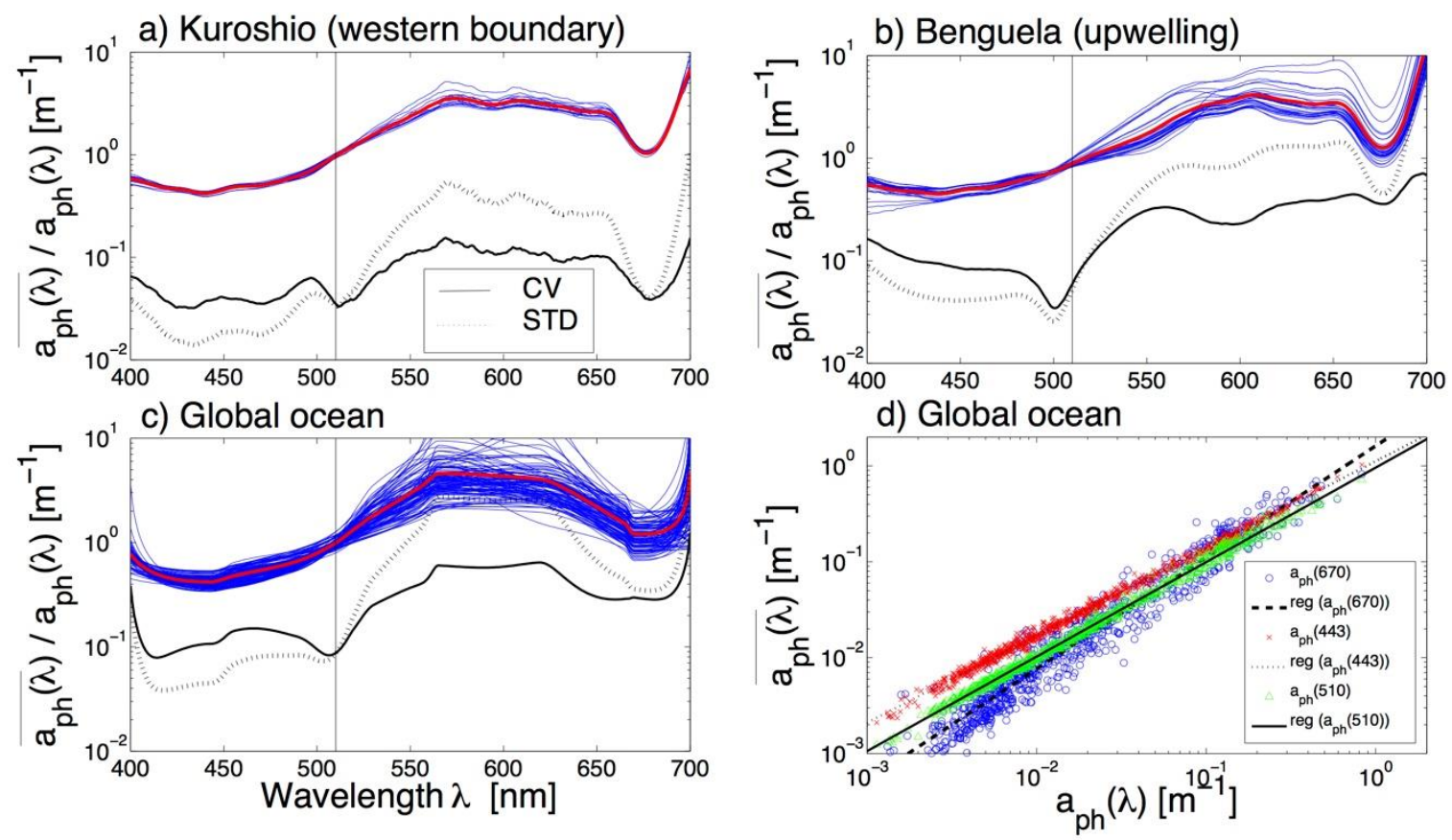

770

Figure 3: The ratio between the spectral average of the absorption coefficient of phytoplankton and the spectral absorption coefficient $\chi_{a p h}(\lambda)$ for three different datasets (blue curves): (a) the Kuroshio water (the Soyo-Maru cruise), (b) the Benguela upwelling waters (the BenCal cruise), and (c) the global oceans (NOMAD, multiple data sources). The thick red curve indicates the average spectrum of the ratio. The black broken and solid curve show the standard deviation (STD) and the coefficient of deviation (CV) of the ratio at each wavelength, respectively. The location of $510 \mathrm{~nm}$ is highlighted as a vertical line in (a)-(c). The scatter plot between $a_{p h}(\lambda)$ and $\overline{a_{p h}(\lambda)}$ for $\lambda=443,510$ and $670 \mathrm{~nm}$ is also shown in (d). 
Biogeosciences Discuss., doi:10.5194/bg-2017-164, 2017

Manuscript under review for journal Biogeosciences

Discussion started: 8 May 2017

(c) Author(s) 2017. CC-BY 3.0 License.
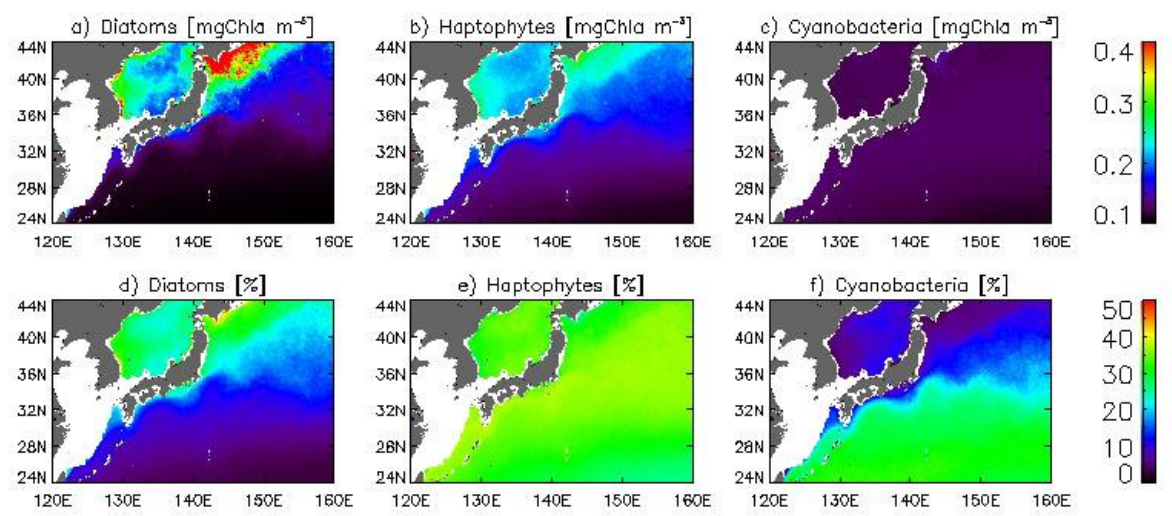

e) Haptophytes [\%]
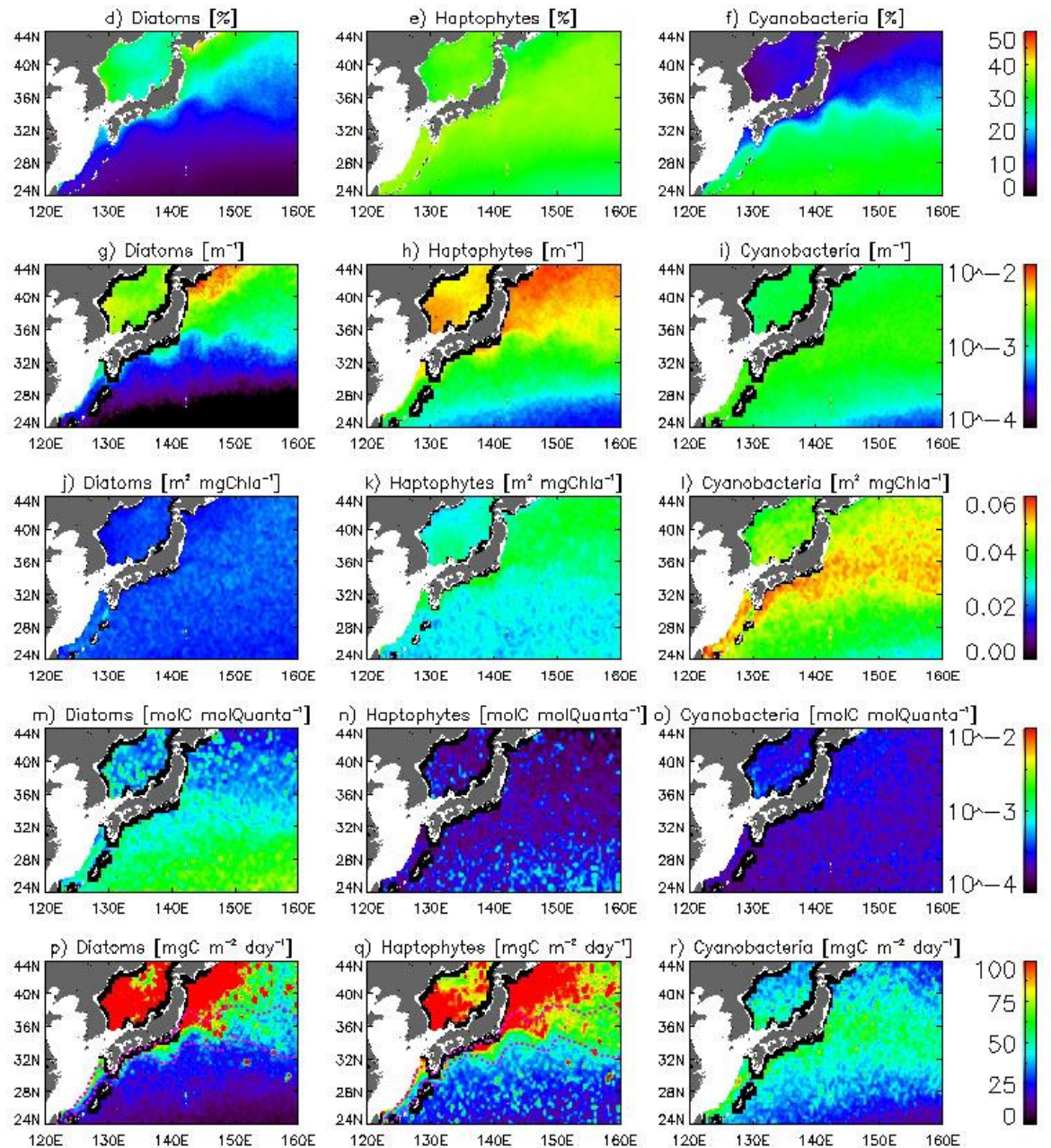

780 Figure 4: Group-specific properties of phytoplankton. Chla $a_{i}$ (a) diatoms, (b) haptophytes, and (c) cyanobacteria; relative Chla abundance: (d) diatoms, (e) haptophytes, and (f) cyanobacteria; $a_{p h, i}(510):(\mathrm{g})$ diatoms), (h) haptophytes, and (i) cyanobacteria; $a_{p h, i}^{*}(510):(\mathrm{j})$ diatoms, (k) haptophytes, and (l) cyanobacteria); $\Phi_{i}^{\#}:$ (m) diatoms, (n) haptophytes, and (o) cyanobacteria; and $P P_{i}$ : (p) diatoms, (q) haptophytes, and (r) cyanobacteria. 
Biogeosciences Discuss., doi:10.5194/bg-2017-164, 2017

Manuscript under review for journal Biogeosciences

Discussion started: 8 May 2017

(c) Author(s) 2017. CC-BY 3.0 License.

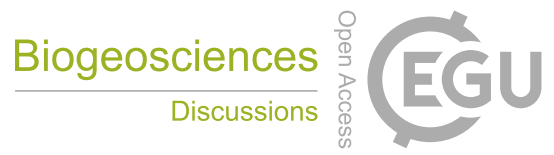

(c) (1)

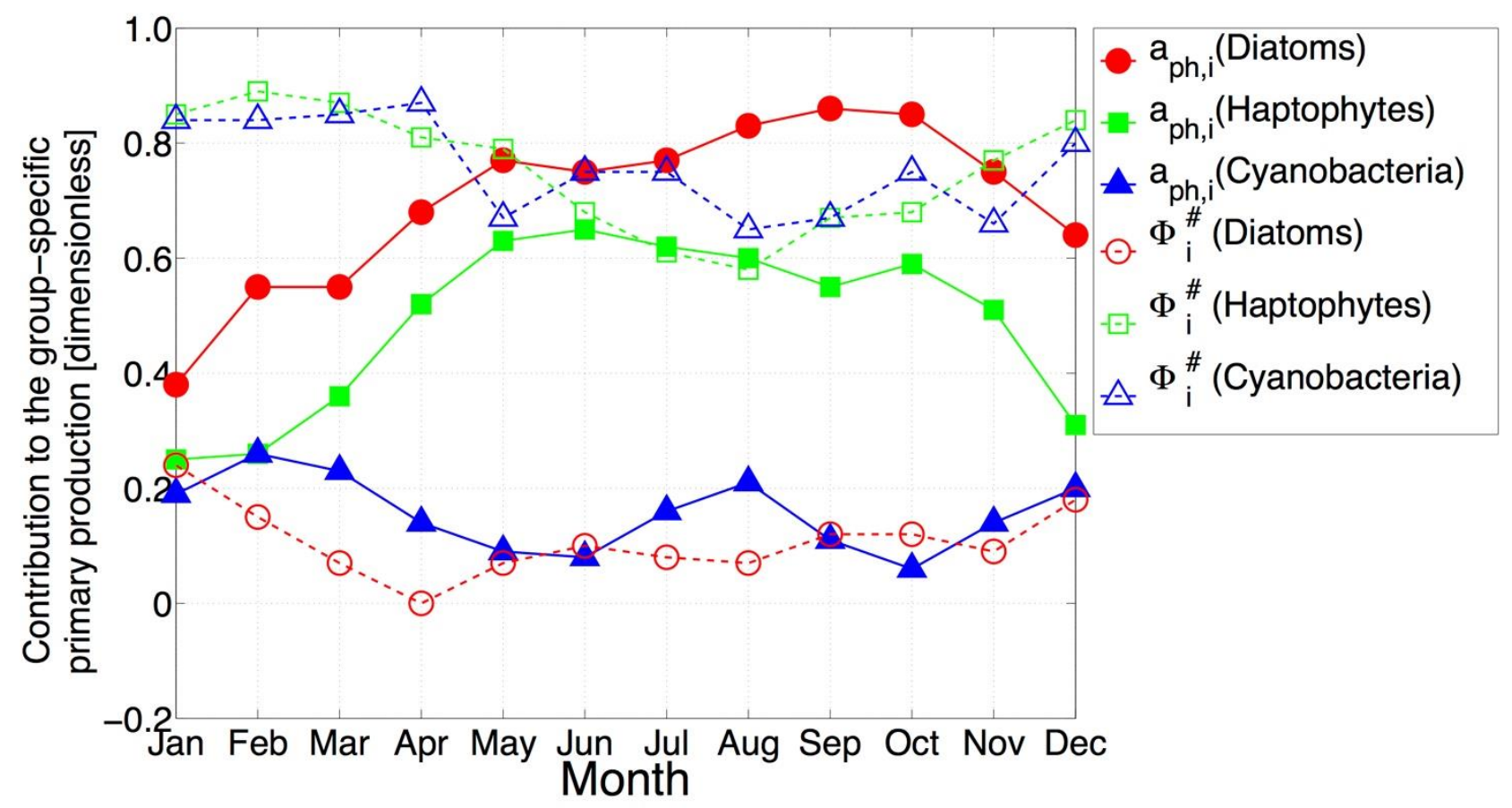

790

Figure 5: Seasonal variability of the relative contribution of $a_{p h, i}(510)$ (dimensionless) and $\Phi_{i}^{\#}$ to $P P_{i}$. Solid curves show the contribution from $a_{p h, i}(510)$ (Chla abundance equivalent), whereas broken curves show the contribution from $\Phi_{i}^{\#}$ (photophysiology). 